\title{
Feios, sujos e muito, muito malvados
}

\section{Migrantes italianos e latinos entre as sombras de Hollywood - breve introdução}

\author{
Maurizio Russo *
}

Eu não sigo ordens de ninguém, a não ser desta [aponta para a própria metralhadora]. Com esta conquistei a Zona Sul e agora me apossarei também da Norte: será a máquina de escrever com a qual gravarei meu nome sobre a cidade inteira.

Antonio 'Tony' Camonte (Paul Muni) em Scarface, The Shame of a Nation (1932) ${ }^{1}$.

\section{O imaginário fílmico sobre a migração, objeto de estudo complexo}

Estudando a natureza e os mecanismos de produção do imaginário cinematográfico, é possível reconstituir uma história da imagem do migrante na sociedade, destacando os estereótipos que definiram a imagem do outro, o estrangeiro. Relacionar a evolução desses estereótipos com a história das sociedades constitui uma contribuição para compreender as raízes de fenômenos atuais, como a xenofobia.

Mas também é possível reconstruir a história da imagem do migrante que se constrói através de um cinema de autor militante, ou preocupado com os problemas sociais. Um cinema que não está direcionado a vender no mercado histórias cinematográficas cheias de estereótipos pejorativos sobre os migrantes,

* Doutor em História contemporânea pela Université de Nancy 2 (France); membro do Diversitas/USP. 
nem utilizar ou fomentar o sentimento xenófobo, o medo do outro ou a fácil banalização ou ridicularização daquele que é culturalmente diverso².

De uma maneira muito geral, podemos dividir este complexo objeto de estudo em dois campos, relacionados numa dialética estética fílmica e unidos por terem como centro de reflexão o fenômeno migratório, sob diferentes aspectos, diferentes perspectivas, diferentes períodos históricos.

De uma maneira esquemática:

a) pode-se analisar a visão estereotipada e pejorativa dos migrantes de um cinema pouco sensível a temáticas sociais, humanitárias, culturalmente pluralistas;

b) ou, estudar a reflexão séria do cinema como um olhar crítico, ou como evidência de um fenômeno socialmente relevante como a migração.

No primeiro caso, o nosso objeto de estudo será composto de um corpus de filmes diferentes entre si, que não têm, necessariamente, a migração como o centro da narração, mas poderiam pertencer à mesma vertente temática (western, gangster-movie, comédia, drama) ou ao mesmo período. Por exemplo, o cinema mudo de gênero policial produzido nos Estados Unidos nos anos 1910 e 1920, quando Hollywood constrói sua primeira visão estereotipada do migrante italiano. Ou, os filmes hollywoodianos nos quais aparece a fronteira Estados Unidos México, para definir a imagem do latino que é apresentada nesses tipos de filmes.

Obviamente, pode-se também fazer um estudo abarcando todos os filmes ou os filmes mais representativos de um determinado país, ou de um determinado período cronológico.

A maioria desses filmes é parte de uma produção que segue as tendências de mercado, com grande atenção aos cânones estandardizados do filme hollywoodiano "clássico". Eles produzem e reproduzem estereótipos. O estereótipo fílmico (imagem, música, frases, situações) apresenta uma forma segura de oferecer ao público um produto já conhecido, que não requer esforço de compreensão. Um cinema ligado ao conceito de industry of entertainment, própria de Hollywood, mas que não é monopólio dos Estados Unidos (um exemplo típico é Bollywood; porém, o fenômeno também existe na França, GrãBretanha, Itália, Japão, Coreia, etc.).

No segundo caso, o objeto de nosso estudo será constituído de filmes que representam uma voz crítica na sociedade, que resultam de uma preocupação de denunciar, testemunhar ou documentar um fenômeno importante como a migração. Trata-se, frequentemente, de um cinema que nasce do comprometimento intelectual do diretor (exemplos desse tipo de cineasta comprometido são Pier Paolo Pasolini, Ettore Scola, Ken Loach, Marco Bechis, Israel Adrián Caetano, Mathieu Kassovitz, Andrea Segre, Abdellatif Kechiche, Eran Riklis, entre outros).

Estes filmes falam de migração, das relações com os outros, das fronteiras sociais e culturais, dos problemas sociais. Visam ampliar e questionar a consciência sobre a questão da migração. São testemunhas de um fermento 
cultural/político que se preocupa com o problema da migração. Eles são, muitas vezes, uma voz crítica sobre a sociedade na qual são produzidos e circulam.

Um exemplo deste tipo de cinema é Il cammino della speranza, de Pietro Germi (Itália, 1950). Um filme que é representante de um fenômeno cultural nascido de uma forte exigência de crítica social. O filme de Germi entra completamente no período histórico e no fenômeno cultural do neorrealismo, corrente artística que, antes de ser cinematográfica, foi, sobretudo, um importante fenômeno literário (Elio Vittorini, Cesare Pavese, Beppe Fenoglio, Alberto Moravia, Vasco Pratolini, Carlo Cassola, e a produção inicial de Italo Calvino). O filme inspira-se no romance neorrealista Cuori negli abissi, de Nino Di Maria, publicado em 1949: história verídica da vida infernal dos mineiros de Somatino, na Sicília, que desesperados, tentam migrar irregularmente para a França, morrendo congelados na travessia dos Alpes.

Il cammino della speranza - a narração da migração clandestina dos mineiros que buscam chegar à França - permanece como um testemunho importantíssimo da migração europeia contemporânea, desfazendo um mito entre os mais sólidos do discurso xenófobo e antimigratório europeu: o fato de que as migrações dos europeus seguiam percursos legais, enquanto os novos fluxos migratórios que chegam à Europa são quase todos irregulares.

Outros exemplos deste tipo de cinema são La haine, de Mathieu Kassovitz (França, 1995); O homem que virou suco, de João Batista de Andrade (Brasil, 1981); Bolívia, de Israel Adrián Caetano (Argentina-Holanda, 2001); Le Havre, de Aki Kaurismäki (Finlândia-França-Alemanha, 2011). Todos estes filmes são expressões de contextos culturais, intelectuais, sociais, políticos diferentes, mas tendo em comum o desejo de evidenciar (de diferentes formas, com estéticas diversas e impacto diferenciado sobre a sociedade da qual eles são expressão) o problema dos migrantes.

Este cinema é um sintoma de uma reflexão cultural-político-social sobre o problema migratório que abre (ou deseja abrir), na sociedade, espaços para reflexão.

Em ambos os casos, deve-se ler o produto filme em uma relação dialética com o período histórico em que este se localiza, entendendo o termo "produto" não apenas no sentido econômico-comercial, mas também no sentido cultural e político. A relação do filme de autor com o âmbito intelectual em que ele é produzido constitui um aspecto fundamental da análise, assim como o adequado contexto histórico, social e político.

O "cinema de autor" não é, de fato, um acaso e, muitas vezes, corresponde a uma verdadeira e própria reflexão sobre o assunto tratado. É o caso daqueles que vivenciaram pessoalmente a migração, como Martin Scorsese, autor de Italianamerican, curta-metragem de 1974, sobre a italianidade de sua própria família; de Gianni Amélio, diretor de Lamerica (Itália, 1994) e Così ridevano (Itália, 1998); ou do escritor e filmaker argentino Edgardo Cozarinsky, autor de Boulevards du crépuscule, sur Falconetti, Le Vigan et quelques autres... en Argentine (Suíça, 1992). 
Mesmo querendo considerar e analisar somente o cinema que trata da migração sob uma perspectiva crítica, (interrogando sobre a responsabilidade da sociedade que recebe ou que expulsa os migrantes), não podemos ignorar a enorme produção da filmografia hollywoodiana que produz e tem produzido (desde os primeiros filmes mudos), como também difunde e tem difundido uma enorme quantidade de estereótipos sobre o migrante. Estereótipos que são reproduzidos cotidianamente nos discursos que escutamos na rua, nos cafés, no metrô; que são utilizados nos comícios eleitorais de movimentos xenófobos (por exemplo, os preconceitos sobre o árabe/terrorista difundidos pela Lega Nord italiana - uma banal sopa requentada, de estereótipos fílmicos a bom preço); que ricocheteiam dos jornais aos debates televisivos.

É importante tentar determinar como os modelos que descrevem os migrantes (italianos, latinos, etc.), e que são impostos globalmente, a partir de Hollywood, são incorporados nas filmografias nacionais de outros países; pois, mesmo que um cinema comprometido ou intelectual não utilize estes estereótipos, os filmes produzidos nunca se colocam no vazio, na ausência de produção fílmica. Há um imaginário fílmico pré-existente, que não pode ser ignorado; um imaginário fílmico hegemônico, produtor de estereótipos, que deve ser levado em consideração.

\section{O mundo através da lente hollywoodiana}

"Nós olhamos o mundo através da lente hollywoodiana dos filmes que inundam nossas sociedades". Esta afirmação de Pierre Sorlin sintetiza de forma muito eficaz a situação do cinema mundial contemporâneo (SORLIN, 1991, p. 4). Ela contém uma grande verdade, que resume o grande poder do cinema hollywoodiano: a) a afirmação de um modelo-industrial fílmico que acaba sendo considerado como "clássico" (história linear, maniqueísmo moral, presença de atores-star, personagens com características bem identificáveis, trilha sonora que acompanha a história, etc.) (cf. BORDWELL, 1986); b) a grande capacidade da indústria hollywoodiana de dominar a distribuição mundial.

Sorlin afirma que, em muitos países, os produtos hollywoodianos representam $70 \%$ da distribuição, e que este índice nunca é inferior a $40 \%$. Tal observação também traz uma consideração implícita sobre os valores contidos nessa grande quantidade de filmes presentes no mercado cinematográfico, bem como sobre a estética fílmica que se faz intérprete e veículo desses valores. No seu famoso ensaio sobre fotografia, Andre Bazin destaca a novidade da fotografia em relação à pintura, indicando-a na sua objetividade, enfatizando que o cinema é, acima de tudo, uma linguagem (BAZIN, 1958). Esta linguagem se compõe e se nutre, em grande parte, de estereótipos: estereótipos artísticos (literários, pictóricos); mas, sobretudo, fílmicos. Estereótipos que são imagens, metáforas, ideias, músicas, alegorias, gestualidades, frases, atitudes, formas de apresentar uma personagem ou uma situação. Uma complexa construção polissêmica, porque o cinema é uma linguagem que contém uma polissemia de estereótipos. 


\section{Rodolfo Pietro Filiberto Guglielmi, na arte, "Valentino"}

Falando de migrantes, o contexto não muda. Existem estereótipos que provêm do cinema hollywoodiano em relação aos migrantes, e os estereótipos têm sua própria história e sua própria evolução. Um dos primeiros estereótipos a ser atribuído ao migrante, e que prevaleceu como marca forte e universal, foi seguramente aquele associado à personagem do amante latino, criado em torno do ator migrado italiano Rodolfo Pietro Filiberto Guglielmi, cujo nome artístico era Rodolfo Valentino. Como explica Giorgio Bertellini, Valentino foi, nos anos 1920, a estrela ícone para a crescente comunidade ítaloamericana, e, principalmente, o estereótipo da virilidade exótica, a qual era estranhamente ligada à repulsão que a mentalidade xenófoba reservava aos "retrógrados" e "bárbaros" migrantes italianos. Encarnação do amante da masculinidade magnética, a figura de Rodolfo Valentino se contrapõe a outro grande modelo de virilidade italiana daqueles anos: o de Benito Mussolini, o Duce, masculino e amante, que doma mulheres e se permite ao luxo, na catolicíssima Itália, de ter uma esposa - Rachele Guidi, mãe-reprodutora, que lhe deu cinco filhos - , e diversas amantes, das quais a mais famosa foi Claretta Petacci (que permaneceu com Mussolini até o fim, e foi com ele fuzilada, em 28 de abril de 1945).

A comunidade italiana nos Estados Unidos era cercada, na época, pela desconfiança e pelo preconceito. Seus membros eram descritos como pessoas que mostravam tendências naturais para a desonestidade, a criminalidade e a obsessão sexual. Os italianos eram colocados no centro de uma visão xenófoba de tipo racista, que distinguia entre os europeus do Norte e europeus do Sul, paradoxalmente baseada em teorias eugênicas de alguns antropólogos e criminologistas italianos, Cesare Lombroso e Alfredo Nicephorus; e, posteriormente, retomada pelo sociólogo americano Edward Alsworth Ross, que argumentou: "Do ignorante, supersticioso napolitano ou siciliano, herdeiro de séculos de desgoverno Bourbon, não se pode esperar que nos comprove o brio de sua raça." ${ }^{3}$ Para Ross, os filhos de migrantes do sul da Itália, nascidos nos EUA, apresentavam um menor grau de inteligência em relação àqueles oriundos do norte italiano; ele duvidava da capacidade deles de aprender, em virtude da origem racial: "Depois de passar por mil perturbações, parece que essas crianças, com a herança dos antepassados sarracenos ou bérberes gravada em suas bochechas, são duas vezes mais vulneráveis a ficar para trás que os alunos da mesma idade, filhos dos imigrantes do norte da Europa, que não falam inglês." 4

Nesse período, o cinema dos EUA constrói sua visão estereotipada do italiano e, especialmente, do migrante italiano: um indivíduo grosseiro e primitivo, de duvidosa moralidade; um criminoso, mafioso e conspirador. Filmes como The Black Hand (A Mão Negra, 1906); In Little Italy (Na Pequena Itália, 1909); Italian Blood (Sangue Italiano, 1911); The Last of Mafia (O Último Mafioso, 1915) criaram um estereótipo do migrante italiano que continha todas as 
características negativas listadas ${ }^{5}$. Esta versão dos imigrantes italianos, inspirada em imagens narrativas cheias de "exóticos pitorescos e, mais frequentemente, na criminalidade da máfia" (BERTELLINI, 2005, p. 702), muda ligeiramente em 1915 , com o trabalho do ator e diretor George Beban, ${ }^{6}$ que inaugurou uma espécie de melodrama racial de fundo sentimental, que oferecia uma imagem "menos repulsiva e mais paternalista dos migrantes italianos" (histórias de abusos racistas, pobreza e trágica fatalidade espetacularizada): The Italian (O Italiano, 1915), The Sign of the Rose (O Sinal da Rosa, 1915-22), Pasquale (Pasquale, 1916), The Loves of Ricardo (Os Amores de Ricardo, 1926). Podese entender esse tipo de cinema como uma visão de uma comunidade que busca se integrar. A descrição das injustiças sofridas, ou de uma vida difícil e dramática, tem como objetivo despertar um sentimento de solidariedade entre o público; porém, mesmo buscando a integração, o italiano é visto como um ser passional e violento, de comportamento excessivo, sexualmente exagerado e instintivamente agressivo.

Era este o panorama, quando Valentino surgiu como o Divo do perfil exótico (de pele escura e pertencente àquela parte da Itália, da qual provinham os migrantes vistos com desprezo e considerados inferiores). Amante latino de olhar carismático, mas também símbolo de uma virilidade mais ambígua e mais refinada do que aquela proposta pelo Duce, Valentino era, ao mesmo tempo, identificado com aqueles migrantes considerados inferiores, que, como ele, eram oriundos do sul da Itália. Nos primeiros filmes, Valentino aparece em papéis de estrangeiros exóticos ou italianos: um gigolô aristocrata, em A Married Virgin (1918); um gângster, em Virtuous Sinner (1919); um príncipe, em Passion's Playground (1920); um rico benfeitor milanês, em Once to Every Woman (1920); um escritor brasileiro, em Stolen Moments (1920).

O sucesso veio pela primeira vez com The Sheik, de George Melford (1921). A presença de Valentino, nesse filme, provocou protestos da parte de quem não queria um protagonista sex-symbol, que não respeitasse os cânones da virilidade considerados normais na época. Embora o sheik Ahmed Ben Hassan, interpretado por Valentino, fosse filho de um pai inglês e de uma mãe espanhola, a sua pele, mais escura do que o normal, representava uma ruptura do estereótipo estético que queria um protagonista masculino com traços rigidamente caucasianos. 0 contraste entre o mediterrâneo Ahmed Ben Hassan e a pálida Lady Diana Mayo (interpretada por Agnes Ayres) tornou ainda mais evidente a dessacralização, e a imposição de um novo estereótipo. Em diversos estudos, a ascensão do sexsymbol Valentino foi considerada no contexto das mudanças do gosto do público, especialmente feminino, que tiveram lugar nos anos 1920; e também no do incremento das fantasias orientalistas no âmbito do imaginário consumista (cf. BERTELLINI, 2005). Em 1921, Valentino foi também o protagonista de The Four Horsemen of the Apocalypse, de Rex Ingram, no qual interpreta a personagem de Julio Desnoyers, neto do fazendeiro argentino que vai viver em Paris (neste filme, vale recordar a famosa cena do tango). 
Em 1922, foram lançados os filmes: Blood and Sand, de Fred Niblo, no qual Valentino interpreta Juan Gallardo, um toureiro espanhol que se deixa matar na arena, por causa de uma desilusão amorosa; Beyond the Rocks, de Sam Wood, em que Valentino interpreta Lord Brancondale, um rico playboy inglês de origem italiana; The Young Rajah, de Philip Rosen, em que Valentino interpreta Amos, uma criança indiana que cresce em uma família dos EUA, até o dia em que volta para a Índia, com o objetivo de salvar o seu povo; e Moran of the Lady Letty, de George Melford, no qual Valentino interpreta Ramon Laredo, jovem hispânico tomado à força para trabalhar num navio. Em 1924, ele atuou em $A$ Sainted Devil, de Joseph Henabery, interpretando o rico fazendeiro argentino, Don Alonzo Castro. Em 1925, ele foi protagonista de Cobra, de Joseph Henabery, no papel do conde italiano Rodrigo Torriani, libertino encantador, cuja fraqueza eram as mulheres. Ainda em 1925, em The Eagle, de Clarence Brown, ele interpreta o papel do tenente do exército russo, Vladimir Dubrovski, que se torna o bandido mascarado Águia Negra, devotado a ajudar os pobres. Em 1926, ele interpreta seu último filme, The Son of the Sheik, de George Fitzmaurice. Neste filme, que é a continuação de The Sheik, de 1921, Valentino desempenha um papel duplo: o de sheik Ahmed Ben Hassan, e o de filho do sheik, também chamado Ahmed; e nele também reaparece a atriz Agnes Ayres, no papel de Diana, a esposa do sheik.

A carreira curta, mas intensa, de Rodolfo Valentino, ajuda a criar e promover o estereótipo do latinlover de origem mediterrânea, uma versão refinada (e, até mesmo, efeminada) do italiano selvagem, irracional e sexualmente obsessivo. 0 olhar magnético e carismático de Valentino, que conquista as mulheres em virtude de uma atração irracional (quase animalesca), está profundamente vinculado às virtudes animalescas atribuídas aos imigrantes italianos, considerados inferiores, porque são irracionais e sub-humanos. A imagem dos migrantes italianos, seres violentos, vistos como bárbaros que somente se dedicam à reprodução, refinase e purifica-se de seus aspectos desagradáveis, para ser proposta ao mercado consumidor cinematográfico em formação nos anos 1920. Tratava-se de um público, sobretudo feminino, embora também masculino (Valentino ditava moda, em termos de escolhas estéticas: roupas, penteados, estilos de vida), que tem os gostos em evolução, propenso a um orientalismo mediterrâneo, no qual o estereótipo do macho reprodutor é revisitado de uma forma mais elegante, mas com um fundo irracional.

\section{Mafiosos e Gângsteres: o imaginário fílmico da perversão social}

O amante latino, encarnado por Valentino, é uma versão refinada da antiga visão estereotipada dos italianos, ele é reduzido ao essencial de sua capacidade de supermacho reprodutor, que atrai a fêmea sem explicação e sem falar, pela força quase hormonal do seu olhar. Entretanto, a força essencial do estereótipo xenófobo original destinava-se a prevalecer e, depois de alguns anos, retorna ao auge o ítalo-americano mafioso. De origem italiana, mas de nacionalidade norteamericana, o ítalo-mafioso descrito pelo cinema americano, nos anos 1930, 
é nativo dos Estados Unidos, mas tem traços de caráter e comportamentais relacionados com sua origem étnica e racial (italiana, mas também irlandesa). Desenvolvendo-se desde a época do proibicionismo, e, especialmente, do advento do som, a versão cinematográfica do ítalo-americano mafioso (seguindo a visão do nativismo e do darwinismo social) confirma a ideia de que a origem racial torna impossível a inclusão construtiva na sociedade.

Esse imaginário fílmico do mal e da perversão social coaduna perfeitamente com o quadro jurídico específico, inventado para o cinema da época: o Motion Picture Production Code, também conhecido como o Código Hays (em homenagem ao seu inventor, o senador republicano William Harrison Hays), que determinava tudo o que era moralmente aceitável na produção cinematográfica. O Production Code foi adotado pelos Motion Picture Producers and Distributors of America ${ }^{7}$, em 1930, e aplicado de forma ativa a partir de 1934; ele definia as regras para proteger os padrões morais do público, e proibia que os criminosos fossem retratados como personagens positivas ${ }^{8}$. Com a proibição de direcionar a simpatia do público para o crime e os comportamentos desviantes, o mal ou o pecado, tornou-se extremamente funcional dispor de algum grupo étnico que tivesse por natureza essa vocação: ítalo-americanos e irlandeses-americanos eram "naturalmente" condenados a ser maus, uma vez que já chegaram com essa vocação, e permaneceram essencialmente corpos estranhos à sociedade americana, devido às conotações raciais (com o agravante, no que se refere aos italianos, de eles serem procedentes do sul Mediterrâneo, uma região ainda mais inferiorizada).

Em 1928, é lançado The Racket, de Lewis Milestone: o primeiro de uma longa série de filmes de gângsteres que representam uma verdadeira mina de ouro para a cinematografia dos EUA. Seu protagonista negativo é um gângster de nome italiano, Nick Scarsi (reminiscência de Scarface, com o apelido de Alphons Capone); enquanto, numa clássica contraposição maniqueísta, o protagonista positivo é um bom policial de nome irlandês, James McQuigg. Em 1930, Little Cesar, de Mervin Leroy (primeiro grande filme do gênero), narra a rápida ascensão e decadência de Cesare Rico Bandello, dito "Rico" (interpretado por Edward G. Robinson), que sonha em estar no topo do mundo do crime. A concentração absoluta de Rico pela conquista do poder, e sua arrogância e temperamento violento tornam-no predestinado a um fim trágico, pagando invariavelmente com a vida por seus pecados (inclusive, talvez, o da origem italiana). Suas características, associadas ao completo desinteresse pelas mulheres (particularidade que também causou controvérsia quanto à suposta homossexualidade da personagem), colocamno numa linha de descontinuidade em relação ao estereótipo construído sobre Valentino, herói positivo, que continha em si uma força irracional e primitiva, mas a canalizava, através de seu olhar, à conquista das mulheres.

Na mesma linha de Little Cesar, encontra-se a outra grande obra-prima desse gênero cinematográfico: Scarface 9 , de Howard Hawks e Richard Rosson, também produzido em 1930, mas somente lançado em 1932, devido aos 
problemas de censura derivados da entrada em vigor do Código Hays. Visando resolver vários problemas com a censura, o filme teve seu final gravado três vezes, levando Howard Hawks, que também foi o produtor, a acrescentar ao título Scarface, o subtítulo The Shame of a Nation (A Vergonha de uma Nação). A personagem principal do filme, Tony Camonte (chamado Scarface), era inspirada na figura real de Alphons Gabriel Capone, nascido no Brooklyn, em 1899. Filho de um barbeiro e de uma lavadeira de origem da Campania (região do sul da Itália), ele se tornou o "número um" do crime organizado em Chicago, e foi conhecido pelo nome de Al Capone ou Scarface Al. O filme conta a ascensão ao poder de Tony Camonte (interpretado por Paul Muni) e de seu braço direito, Guino Rinaldo (interpretado por George Raft). Cego pelo ciúme de sua irmã Francesca, "Cesca" (interpretada por Ann Dvorak), Tony mata o próprio amigo Rinaldo, e, em final trágico, é morto com Cesca em um tiroteio com a polícia. Violento, irracional, exagerado na ânsia de poder, Tony Camonte não segue nenhuma regra moral, nenhum princípio; sua única verdadeira lei é a da violência, levando-o a afirmar que não recebe ordens de ninguém, a não ser de sua metralhadora. Tudo isso faz de Tony Scarface Camonte (como também de seus amigos ítalo-americanos, e de sua própria irmã) a vítima ideal, para ser sacrificada em nome das rígidas regras do Código Hays.

\section{Assassinos nas sombras}

Numa época em que a indústria cinematográfica dos EUA era povoada de filmes violentos que se baseavam em histórias de conquista e opressão, de pessoas que faziam justiça com as próprias mãos, e de bandidos e aventureiros, o cinema western foi surgindo como um gênero independente. Apesar disso, muitos filmes (entre 1905 e 1915, foram produzidos cerca de 640-650 filmes de curta e média metragem), que tratavam de temas ambientados no Wild West, eram simplesmente rotulados como filmes de aventura, distinguindo-se entre Indian Pictures (estórias de nativos americanos); Civil War Stories (episódios da Guerra de Secessão) e Western Pictures (estórias do faroeste, a vida dos cowboys ou dos pioneiros).

Essa tendência, que, mesmo nos anos 1930, começou a se tornar um gênero fílmico plenamente reconhecido, foi precedida e preparada culturalmente por uma literatura dedicada a esses mesmos temas (como The Last of the Mohicans, escrito em 1826, por James Fenimore Cooper). O tema central da cultura western era a frontier (fronteira), que, ao contrário do conceito juridicamente definido pelo direito internacional, não apresenta uma linha clara entre os estados, mas corresponde ao limite da ecúmena ocupada pelos brancos. Um território ocupado por pioneiros e colonos, que se deslocam gradualmente, mas também inexoravelmente, para o Oeste: uma zona geograficamente vaga, hostil e selvagem, onde a lei ainda não foi imposta de maneira uniforme; uma região caracterizada por relações violentas. 
A frontier é, portanto, um conceito fluido, em movimento, e que não é definido pelos tratados e regulado pela lei, mas sim, ligado a uma conquista constante e violenta. E o cinema western é a história ou as estórias dessa conquista violenta.

Desde The Great Train Robbery, de Edwin S. Porter, filme mudo de 1903 (o filme conta, em 10 minutos e 24 segundos, um roubo no trem), a violência é um dos protagonistas do gênero western. A idade de ouro do western começa na década de 1930, e continua até os anos 1950. Vem à luz obras consideradas clássicas como Stagecoach, de John Ford, e protagonizado por John Wayne (1939); North West Mounted Police; de Cecil B. De Mille, e interpretado por Gary Cooper (1940); Red River, de Howard Hawks e Arthur Rosson, com John Wayne e Montgomery Clift (1948); High Noon, de Fred Zinnemann, com Gary Cooper, Grace Kelly e Lee Van Cleef (1952); Shane, de George Stevens, com Alan Ladd (1953); The Searchers, de John Ford, com John Wayne (1956). Todos estes filmes movem-se no mesmo panorama moral vago e violento, determinado pelo conceito de frontier. Às vezes, os bandidos são os heróis no centro da estória: como, por exemplo, em The Lawless Breed, com Rock Hudson (1952), que se baseia nas memórias de John Wesley Hardin, uma figura popular do fora da lei do século XIX, e que, no filme, esforça-se em convencer o filho a não se tornar um bandido.

A falta de legislação não é, muitas vezes, apenas um elemento do quadro contextual, mas torna-se também o centro da estória: como em The Man Who Shot Liberty Valance, de John Ford, e interpretado por John Wayne, James Stewart, John Carradine e Lee Van Cleef (1962). Neste filme, é narrada a estória de um advogado que vem do Oriente civilizado, e descobre um mundo onde suas crenças não são aceitas. O filme representa a afirmação de que, com um olhar de cidadãos do Oriente respeitosos das regras, não é possível compreender a frontier.

Mas como poderia a moral cinematográfica da época do Código Hays ignorar toda essa maré de violência, de sangue, de falta de lei? Evidentemente, a métrica moral com que se mede a violência é completamente outra.

No filme Scarface, acontecem cerca de 20 assassinatos, que, devido à orientação imposta pelo Código Hays, nunca são filmados diretamente: é muito famosa a cena de abertura, em que o assassinato do gerente de um restaurante (representando o início da estória criminal narrada) é feito em longo planosequência, que incorpora a sombra do assassino aproximando-se da vítima, sem nunca mostrar diretamente o crime (tanto o assassino, como a vítima); embora mostrando, sem reservas, as mortes violentas dos bandidos. São especialmente dramatizadas, com grande ênfase e intenção moralizadora, as mortes de Scarface-Camonte, Rinaldo e Cesca. Já, em Stagecoach, de John Ford, é somente na cena do último ataque à diligência, que se assiste a aproximadamente quinze mortes violentas, em pouco mais de 7 minutos (incluindo as de alguns nativos pisados, ou puxados por cavalos).

Tudo isso levanta uma questão óbvia: por que Scarface e Rinaldo devem matar de forma oculta (obscurecidos pela censura que lhes nega a visibilidade 
concedida a cada protagonista digno de respeito), enquanto John Wayne \& co. podem se dedicar a abater, abertamente, à luz do sol, dezenas de pessoas e também dois inimigos, com um só golpe?

Essa flagrante diferença é reivindicada como legítima, e também justificada num diálogo que acontece em Scarface, de Hawks e Rosson, entre um jornalista e o chefe dos detetives de polícia:

Jornalista: Diga, chefe!

Chefe: $O$ que você quer?

Jornalista: Este companheiro, Camonte.

Chefe: $O$ que tem ele?

Jornalista: Uma história. É um tipo daqueles que o público gosta, é um tipo pitoresco.

Chefe: Pitoresco? O que há de tão pitoresco num piolho rastejando? Eis aí o erro de muitos de nossos jornalistas: fazem dessa máfia uma espécie de semideuses. Em que se transforma Camonte nos jornais? Num herói popular e romântico, num campeão esportivo. Os jornalistas tinham alguma desculpa para glorificar nossos velhos bandidos Western. Eles se enfrentavam no meio da rua ao meio-dia, mão na pistola e olho no olho; mas, não esses vermes, que disparam por trás das pessoas.

A violência dos bandidos (e também a violência generalizada) pode, então, ser glorificada nos filmes Western, nos quais se aplica a moral incerta e aproximativa da Frontier; mas, deve ser condenada nos filmes que narram sobre as cidades civilizadas do Oriente. Entretanto, isso não acontece somente porque o gênero Western destaca um dos mitos fundadores dos EUA, aquele do Far West, (feito, em grande parte, de violência: Guerra de Secessão, guerras indígenas, massacres, duelos e tiroteios); mas também, porque sempre, graças a uma visão fortemente maniqueísta, o cinema-indústria vendia uma imagem do inimigo social, que era determinista, racista e darwiniana. Em Stagecoach, o inimigo é representado pelos Indians, selvagens e bárbaros que se movem silenciosamente na sombra, para atacar por trás. Eles não fazem parte do projeto civilizador simbolizado pela diligência ou pelo trem que cruza as vastas pradarias. Mesmo que estivessem presentes nas pradarias, antes da chegada da diligência e do trem, eles não poderiam participar do projeto, já que são seres inferiores desde o nascimento e, portanto, condenados à extinção; seu extermínio é um ato natural, que simplesmente acelera um final predestinado e previsível.

Em Scarface, os inimigos são os bandidos, nascidos cidadãos norteamericanos, mas que pelas disposições do Código Hays, estão condenados a agir na sombra. Tanto no primeiro caso, como no segundo, as sombras fazem parte daquela visão maniqueísta, simplista e moralista, que fez a fortuna do cinema hollywoodiano. Os bandidos do Far West enfrentavam-se durante o dia, olho no olho, num meio-dia de fogo. Eles eram, mesmo que bandidos, seres de luz e, portanto, do bem. O papel dos seres noturnos, silenciosos, que se movem nas sombras às quais pertencem, era destinado aos Indians, pois isso era conveniente 
e integrava a sua própria essência perversa; era uma característica da sua raça. O seu pertencer ao mundo das sombras indicava-os como predestinados a desaparecer. Do mesmo modo, tasmbém pertencem ao mundo das sombras os gângsteres ítalo-americanos de Scarface e Little Cesar. Assim como os índios do gênero Western, eles não entram no projeto civilizador norte-americano, já que também pertencem a uma raça considerada inferior. Embora especificamente incluídos no tecido social e econômico, mesmo que nascidos na mesma cidade do Leste de onde partem os pioneiros civilizadores do Far West, eles permanecem, no imaginário fílmico, como corpos estranhos e nocivos que é permitido eliminar; eliminação esta, que é prevista como um evento positivo na estética fílmica do cinema de gângster daqueles anos.

\section{Il Padrino, a normalização do crime}

Depois dos anos 1930, o gênero gangster-movie entra em declínio, mas a figura do gângster de origem italiana continua a ser uma constante. A personagem de Al Capone retorna em 1967, com The St. Valentine's Day Massacre, de Roger Corman. Contudo, é em 1972 que o mafioso ítalo-americano reconquista o papel de protagonista do cinema hollywoodiano, impondo-se, desta vez, como uma personagem negativa, mas carismática, e que tem regras morais, mesmo que não respeite a lei. The Godfather, de Francis Ford Coppola (com Marlon Brando, Al Pacino, James Caan, Robert Duvall, Diane Keaton), é a reafirmação - como nunca houve antes -, tanto do gangster-movie, como do mafioso italiano. 0 filme, que alcançou um enorme sucesso em todo o mundo, conta a saga da família Corleone, uma organização criminosa de origem siciliana, que controla a máfia em Nova York, no final dos anos $1940^{10}$. Com este filme, o gênero renasce e os estereótipos mudam, não mais retratando o bandido como um psicopata, mas como um hábil criminoso, capaz de manobrar os acontecimentos. O protagonista, Don Vito Corleone (Marlon Brando), encarna plenamente o estereótipo, que se tornou clássico, do mafioso que tem um código de honra próprio, que pratica o mal por ideal, por valores compartilhados (família, amigos, o próprio povo). Ele é temido, mas também respeitado; administra a lei (sua própria lei e a da família) e gerencia os negócios da família, mais como um businessman, do que como um bandit ou um mobster.

Os novos temas do Gangster-movie, bem como os novos estereótipos estéticos sobre os ítalo-americanos, são também utilizados por Martin Scorsese, naquela que foi chamada a sua trilogia da máfia: Mean Streets $(1973)^{11}$, Goodfellas (1990) ${ }^{12}$ e Casino $(1995)^{13}$.

Para completar o quadro, devemos lembrar também outros filmes importantes que retratam mafiosos ítalo-americanos: Capone, de 1975, dirigido por Steve Carver, com Ben Gazzara e um jovem, Sylvester Stallone; Untouchables, de 1987, dirigido por Brian De Palma, e estrelado por Kevin Costner (Eliot Ness), Charles Martin Smith, Andy Garcia, Robert de Niro (Al Capone) e Sean Connery; 
Miller's Crossing, de 1990, dirigido pelos irmãos Coen, com Gabriel Byrne, Marcia Gay Harden e John Turturro; A Bronx Tale, de 1993, dirigido por Robert de Niro, com o próprio, além de Chazz Palminteri; Donnie Brasco, de 1997, dirigido por Mike Newell, e estrelado por Al Pacino e Johnny Depp.

Devemos também mencionar Once Upon a Time in America, de 1984, dirigido por Sergio Leone, e interpretado por Robert De Niro, James Woods e Elizabeth McGovern. O filme narra a história de David Aaronson, chamado "Noodles" (Robert De Niro), e seus amigos do gueto judeu e do ambiente do crime organizado em Nova York, do proibicionismo e pós-proibicionismo. Embora o gangster ítalo-americano faça apenas parte do contexto, o filme é um importante testemunho da evolução da imagem do ítalo-americano criminoso.

Um lugar especial entre esses diretores deve-se a Martin Scorsese. Filho de ítalo-americano e autor de um interessante documentário sobre seus pais, Italianamerican, de 1974, em que aborda a experiência de imigrantes italianos em Nova York, da família Scorsese. Os argumentos são: a família, a fé, as origens, os parentes italianos, a vida na Itália do pós-Guerra, as condições de vida dos imigrantes sicilianos nos Estados Unidos (também descritas em várias obras posteriores do diretor). Os temas centrais de seus filmes são a culpa, o pecado e a religião. Sua concepção do cinema, inspirada na Nouvelle Vague francesa, no Neorrealismo italiano, e ainda, no cinema independente de John Cassavetes, representou importante ruptura dos paradigmas hollywoodianos. Expoente da New Hollywood ${ }^{14}$, Scorsese tem o mérito de incluir em seus filmes, especialmente em Mean Streets, certa perspectiva antropológica e sociológica, que além de explicar o ambiente, não reduz os protagonistas a simples estereótipos.

\section{The Sopranos, a banalização do crime}

Os estereótipos cinematográficos mudam, adaptando-se à sociedade (com a qual interagem), à cultura política e, especialmente, ao mercado. Eles são complexos, e compostos de imagens, discursos, conceitos, definições, ambientações, descrições. O simbolismo dos filmes, marcado pelos estereótipos, deve ser interpretado, contextualizado e comparado com outras obras cinematográficas anteriores e contemporâneas.

É evidente que a personagem de Al Capone, em sua evolução, desde o seu primeiro protótipo (o Nick Scarsi, em The Racket, de Lewis Milestone, de 1928), parece a encarnação do gângster violento e sem escrúpulos. Um corpo estranho que a sociedade só pode rejeitar, apagar, tal como "a crawling louse" ("um piolho rastejando"). Esta imagem se reforça e se concretiza, especialmente no filme Scarface, de Hawks e Rosson, de 1930, e permanece nas décadas posteriores.

Por outro lado, Vito Corleone (tanto o adulto, interpretado por Marlon Brando; como o jovem, com Robert De Niro) e também seu herdeiro, Michael Corleone (Al Pacino), são a evolução do gângster ítalo-americano, apresentado, desta vez, como um produto da sociedade; um desviante das regras da sociedade, 
mas que tem ideais, princípios e, acima de tudo, interesses econômicos dignos de respeito.

Nos anos 1970, o cinema dos EUA estava construindo um novo estereótipo do perigo migrante. Os italianos perdiam, assim, a primazia, e retornavam apenas numa visão estereotipada útil ao mercado da imagem, mas agora destinada ao mercado televisivo. De 1959 a 1963, a série televisiva The Untouchables, transmitida pela $A B C$ (American Broadcasting Company), oferece novamente ao grande público a imagem estereotipada do criminoso de origem italiana. Situado no início dos anos trinta, o seriado narra a história do agente Eliot Ness (interpretado por Robert Stack), que prendeu Al Capone, e também a de sua equipe, The Untouchables (Os Intocáveis) ${ }^{15}$. Tornou-se um dos programas mais populares da época, propagando amplamente (em suas quatro temporadas) o estereótipo do criminoso ítalo-americano. Nele, todos os criminosos falavam com sotaque italiano, e isso levantou muitas controvérsias, levando a que, na segunda temporada (1960-1961), começassem a também aparecer criminosos de outras origens culturais e migratórias ${ }^{16}$.

Recentemente, temos a série de grande sucesso na $\mathrm{HBO}^{17}$, The Sopranos (com seis temporadas, das quais a última foi transmitida tanto nos EUA, como na Itália, em 2006-2007). Ela retrata a vida de Tony Soprano (interpretado por James Gandolfini), ítalo-americano mafioso, chefe da família Soprano, originária de Avellino, e que vive em Nova Jersey, e tem contatos importantes com as gangues de Nova York, além de negócios com a camorra napolitana.

The Sopranos também provocou muitas polêmicas: o National Italian American Foundation criticou fortemente a série, alegando que ela facilita a divulgação dos estereótipos típicos ítalo-americanos, como mafiosos, adúlteros e portadores de uma subcultura que tem como principais características a violência e a vulgaridade intelectual. Estereótipos simplificados e negativos que, do ponto de vista verbal, manifestam-se em linguagem grosseira e agramatical usada pelos principais protagonistas.

O grande sucesso de The Sopranos vem do feito de interpretar e propor, através de estereótipos simplistas (que favorecem sentimentos racistas), a própria essência da sociedade americana. Nesta série, fica absolutamente claro que, em um mundo dominado por valores materiais, a luta pelo progresso na escala social não é apenas um jogo emocionante, como é o único jogo que importa. Suas personagens são motivadas pelos mesmos valores essencialmente materiais que movem a maioria dos americanos, dos guetos até Wall Street, incluindo os escritórios executivos de grandes empresas multinacionais.

O novo estereótipo afirmado por The Godfather transformou a imagem, já batida e pouco vendável do crime organizado numa grande saga familiar, ligando-a a um dos valores típicos da retórica cinematográfica hollywoodiana: a família. Como explica Rudolf J. Veicoli: "Este louvor da via vecchia, em que a autoridade patriarcal, lealdade pessoal e piedade filial criavam a ordem e a justiça, capturava um desejo geral de segurança num mundo cada vez mais amoral e caótico. 
Enquanto as organizações de ítalo-americanos protestavam e faziam boicotes ao filme, muitos ítalo-americanos o acolheram como a encarnação icônica de sua herança e identidade" (VECOLI, 2002, p. 84). Tal processo, iniciado em 1972, com The Godfather, culmina em 1999-2006, com The Sopranos, quando da figura quase mitológica do Padrinho Don Vito Corleone, passa-se ao neurótico e combativo Capo Famiglia Tony Soprano.

Vito Corleone é tranquilo, altruísta e religiosamente respeitado; o depositário de uma sabedoria antiga que vem das velhas tradições de sua pátria original. Sua figura transforma, simbolicamente, a vergonha de ser um migrante numa qualidade positiva, um motivo de orgulho.

Tony Soprano, em contrapartida, é cheio de contradições, tem uma difícil relação com a mãe autoritária, vive o descompasso entre ser chefe da máfia e um pai afetuoso, e é incapaz de aceitar os diferentes papéis que deveria ter (amante, amigo, chefe da máfia), sendo, por isso, levado a fazer terapia. Tony representa o típico americano burguês de média cultura do século XXI, à mercê de acontecimentos e situações perturbadoras, que não compreende, - como a política internacional, as diferenças sexuais (por exemplo, a homossexualidade) -, e que é tomado de sentimentos de culpa e de desejos insatisfeitos.

Uma década após o lançamento de The Godfather, sinal explícito da mudança do estereótipo cinematográfico sobre ítalo-americanos, reaparece a figura de Al Capone, o mafioso infame que não merece piedade. Em Scarface, de 1983, escrito por Oliver Stone, dirigido por Brian De Palma, e estrelado por Al Pacino, Steven Bauer e Michelle Pfeiffer, verificam-se muitas mudanças em relação ao filme de Hawks e de Rosson, de 1932: a ação é transferida da Chicago do Proibicionismo para a Miami dos anos 1980, o centro do tráfico de drogas; o protagonista não é um ítalo-americano, mas um imigrante cubano, Antonio "Tony" Montana (Al Pacino).

O filme começa retomando um episódio histórico das relações entre Cuba e os Estados Unidos: o famoso Éxodo del Mariel. Em 1980, Fidel Castro permite que aproximadamente 125 mil cubanos saiam de Cuba para chegar aos Estados Unidos, tanto para responder à política norte-americana, que encoraja os cubanos a escapar da ilha e se exilar nos EUA, como para esvaziar as superlotadas prisões cubanas. Todos os migrantes cubanos embarcam na baía de Mariel. É com esses "exilados políticos" que Tony Montana chega a Miami. Sua personagem é descrita como violenta, irracional, cruel, sanguinária e obcecada com o luxo. A maneira de comportar-se - violenta e impulsiva -, faz dele uma personagem imprevisível. Seus movimentos são guiados por instintos primitivos e egoístas. Al Capone volta, portanto, em toda a sua essência violenta e animalesca; mas não é forçado a matar na sombra, ou escondido no quarto: haja vista a cena final, em que Tony, antes de morrer, enfrenta sozinho dezenas de assassinos enviados por um poderoso traficante boliviano. Na realidade, os principais protagonistas da cena são dois: Tony Montana e o que ele chama de "meu amiguinho", um Colt AR-15 com uma Fake M203 grenade launcher 
(lançador de granadas). Percebendo que havia cinco assassinos latinos à porta e prestes a entrar em seu quarto, Tony explode porta e homens com uma granada de $40 \mathrm{~mm}$ e exclama: "Digam olá para o meu amiguinho!" ${ }^{18}$. Assim como o Scarface de 1932, que recebia ordens somente de sua metralhadora, Tony tem como único amigo uma máquina de guerra. O Colt AR-15 little friend de Tony Montana tomou o lugar do Tommy Gun (submetralhadora Thompson) de Al Camonte.

No filme de De Palma, as mortes são sangrentas, violentas e explícitas. As armas têm um papel importante e existem em grande quantidade e variedade: pistolas (Beretta Modelo 81, Beretta M951, Colt Python, Smith \& Wesson Modelo 36, M1911A1), rifles (Remington 870, Spanish Zabala Sawed-off Double-barreled Shotgun), metralhadoras e fuzis de assalto (MAC-10, Uzi, FN FAL, Heckler \& Koch HK33, Valmet M82A, Colt AR-15 with Fake M203 grenade launcher, M16A1).

A cena da morte de Tony é um condensado altamente significativo da nova imagem do criminoso cinematográfico que está emergindo. No filme de De Palma, esta imagem é bem definida a partir de características gerais que formam a matriz comum para uma grande variedade de criminosos: o melhor exemplo é o pequeno exército de narcos, que enfrenta o protagonista na cena final. Quer seja um bandido com olhar selvagem e cabelo comprido, ou um gordinho com um rosto redondo e bigode; um assassino silencioso que golpeia mortalmente pelas costas, ou mesmo Tony Montana numa cara roupa de grife, o criminoso é perigoso, sempre armado, não dá valor à vida, suas ações são pura violência destrutiva e mortal, e, principalmente, o criminoso é hispânico.

Al Capone, o símbolo do criminoso psicopata, a personificação do mal, torna-se latino, enquanto ao ítalo-americano (mas também de origem irlandesa) destinam-se estereótipos criminais mais aceitáveis e socialmente "justificáveis", até chegar à personagem de Tony Soprano.

Em The Sopranos, o ítalo-mafioso assume sempre mais as conotações de homem médio, no qual a violência e a ilegalidade são permitidas, pois servem para fazer carreira e melhorar a sua situação econômica ou a sua própria qualidade de vida ou da sua família. A moral que vale para o ítalo-americano Soprano não é aquela super partes da lei, mas aquela do egoísmo familiar, social e do individualismo. Obviamente, os latinos também (e, particularmente, os mexicanos) têm uma longa história de estereótipos que povoa o cinema holywoodiano, desde o início do século XX.

\section{Feios, sujos and greasers: os latinos de Hollywood}

Desde os primeiros filmes western, os mexicanos que se moviam no espaço da frontier tinham direito a seu próprio estereótipo, o greaser, do qual deriva a imagem do bandido mexicano e, mais tarde, latino. Greaser era a palavra com a qual eram chamados os mexicanos que trabalhavam como transportadores com carro puxado por uma mula. Esta definição (gordura/engordurado) deriva da 
gordura utilizada para lubrificar o eixo dos carrinhos, (principal instrumento de trabalho dos mexicanos), indicando que eles eram sujos e repugnantes.

O greaser-movie representou um verdadeiro e próprio subgênero dentro do cinema western, alcançando bom êxito na era do cinema mudo: Ah Sing and the Greasers (1910); The Greaser's Gauntlet (1908); Tony the Greaser (1911); The Greaser and the Weakling (1912); The Girl and the Greaser (1913); The Greaser's Revenge (1914); Bronco Billy and the Greaser (1914); The Greaser (1915).

Nesses filmes, o greaser é o antagonista, o mau, el bandido. Tem pele escura, é baixo, sujo, com roupas imundas, besuntado (gorduroso), com longa barba, é desdentado, despenteado, e tem cicatrizes e sobrancelhas espessas. Ele é naturalmente inclinado ao mal, ao vício e à crueldade. Suas ações não têm orientação moral: ele despreza a lei e a sociedade. A versão feminina do estereótipo/bandido mexicano é a prostituta: cabelos negros, lábios carnudos, corpo sexy, baixa inteligência, dependente de seus impulsos sexuais e dos homens. O corpo da mulher mexicana é reduzido à sua função essencial de objeto sexual (GIRVEN, 1994).

O estereótipo pejorativo do greaser está na raiz de muitos estereótipos sobre latinos desenvolvidos no cinema norteamericano (KLAHN, 1994; QUART Y AUSTER, 1984). Na construção do estereótipo do latino, a frontier desempenha papel fundamental. Entre 1921 e 1928, Hollywood produziu 75 filmes em que aparecia a fronteira entre Estados Unidos e México (GARCíA, 1988), contribuindo substancialmente para a construção do estereótipo do México e dos mexicanos no imaginário coletivo dos norte-americanos. Especialmente nessa época, Tijuana assume um forte significado simbólico, convertendo-se em cidade de fronteira; considerada parte da frontier (com toda a carga simbólica de território bárbaro, sem lei, habitado por selvagens), ela é a própria imagem do México (entre 1924 e 1935, 19 filmes mostravam cenas de Tijuana). Não é por acaso que o primeiro filme sonoro que lida com os latinos que lutam com o sonho americano é chamado de Bordertown ${ }^{19}$. Dirigido por Archie Mayo, em 1935, o filme narra a estória de Johnny Ramirez, jovem advogado mexican american (americano de origem mexicana) interpretado por Paul Muni (o mesmo que estrelou Scarface em 1932). Depois de obter seu diploma de Direito na Pacific Night Law School, em Los Angeles, Johnny Ramirez, que sonha em se tornar um membro da Suprema Corte, chega triunfante ao seu primeiro julgamento. Entretanto, incapaz de se preparar adequadamente, não consegue defender o seu cliente, um hispânico que perdeu seu caminhão em um acidente causado por uma jovem rica e inconsciente, Dale Elwell (interpretada por Margaret Lindsay). Provocado pelo brilhante advogado que defende a bela Dale, Johnny Ramirez perde o controle, ataca seu adversário e é expulso da Ordem. Falido como advogado, ele cruza a fronteira e vai para uma cidade mexicana, onde encontra trabalho como segurança em um cassino de baixo nível, que ele transforma em um local de classe, o Silver Slipper. A esposa de seu patrão, 
Marie Roark (interpretada por Bette Davis), apaixona-se por ele, e mata o próprio marido para poder amá-lo; mas, Johnny é atraído pela mundana Dale. Assim, depois de se tornar dono da Silver Slipper, ele segue para Los Angeles para declarar a Dale o seu amor. Ela o rejeita com desprezo, apontando as grandes diferenças raciais e econômicas que existem entre eles. Neste momento, Johnny renuncia às ambições de escalada social, vende o Silver Slipper, e passa a viver em Los Angeles, em um bairro de mexican american.

Como afirmado por Mario Alberto Garcia Velazquez, este filme é "el prototipo de la visión de Hollywood sobre los chicanos en su adaptación a la sociedad estadunidense, y muestra actitudes contradictorias hacia la asimilación de estos nuevos grupos de migrantes o la de sus hijos" (VELAZQUEZ GARCIA, 2008, p. 49).

$O$ fatalismo presente ao longo da narrativa tende a mostrar que, para obter sucesso na sociedade norte-americana, os latinos devem abandonar completamente a própria identidade cultural. Cada escolha de compromisso está fadada ao fracasso e leva aquele que a faz até um destino desastroso e imoral. Para os latinos, a opção está em viver de acordo com seus princípios, em áreas que a sociedade lhes concede e reconhece como legítimas. Nesse território, destinado à reconstrução dos valores da identidade hispânica, existe espaço e possibilidade de viver de acordo com sua própria moralidade; e escapar desse território, geográfica e culturalmente limitado, configura fuga da moralidade. A integração passa pelo caminho da formação de guetos.

O sonho americano, o the American way para o sucesso, pressupõe dedicarse inteiramente ao objetivo da ascensão social, do triunfo econômico e da afirmação pessoal. Porém, tudo o que é oferecido, continuamente, através do estereótipo mais paradigmático do herói hollywoodiano - o do indivíduo que luta contra a sociedade e contra todas as adversidades da vida (fazer uma carreira, ter uma posição financeira sólida, uma boa casa, uma boa família e filhos, e, então, ter o direito de perpetrar a sua própria linhagem produtiva na sociedade) - é negado à minoria, à etnia, a quem quer manter a sua identidade cultural, e não renuncia em nome da adesão às regras gerais do American way of life.

\section{The frontier: quando o estereótipo desenha o campo do imaginário fílmico}

A fronteira é um lugar simbólico importante do imaginário cinematográfico norte-americano e mexicano. Cidades e aldeias na área de fronteira são convertidas, rapidamente, em áreas onde a lei se torna bastante difusa e flexível, onde nascem os estereótipos fílmicos que ainda persistem e são transmitidos (transformado-se), ao longo do século XX.

Este espaço simbólico é alcançado por alguns motivos típicos (para escapar da lei; para mudar de vida; para buscar fortuna; para realizar atividades ilegais). A fronteira México-Estados Unidos é una tierra de nadie, onde se exalta a chance de ser livre, embora esta liberdade pareça estar condicionada ao pertencimento 
a um grupo étnico ou nação. O cowboy ou pionier pode, ao invés, escolher tornarse um Sheriff, e estar do lado da lei; ou então, ficar de fora das regras, tornandose um Outlaw. Em ambos os casos, ele pode ser um herói. Não é caso raro o filme ter duas personagens principais: uma boa e uma má; dois representantes desta dupla opção. Como, por exemplo, em 3:10 to Yuma (1957), de Delmer Daves, no qual Dan Evans (aka Van Heflin), um criador de gado em dificuldades econômicas, aceita um emprego como vice-sheriff, para poder colocar na prisão Ben Wade (aka Glenn Ford), um perigoso outlaw ${ }^{20}$. Contudo, o malvado Ben nada mais é do que o alter ego do bonzinho Dan; e assim, durante a viagem que os leva para pegar o 3:10 to Yuma, eles aprendem a se respeitar mutuamente. Dan e Ben são as duas opções possíveis no espaço fílmico da Frontier. Porém, essa possibilidade de escolha não é dada a todos: a ela não têm direito os greasers mexicanos, os índios, os negros e/ou chineses.

A Frontier é um espaço simbólico, que promete liberdade infinita (mesmo para além dos limites normais permitidos por lei), multiplicando as possibilidades do American way, mas apenas para aqueles que têm direito. Ela é um território de contornos geograficamente vagos e conteúdos morais flexíveis, mas com rígidas regras raciais. Seu forte simbolismo reside na sua própria imprecisão geográfica (o símbolo do status in fieri do trabalho civilizador), mas também na rigidez das suas hierarquias raciais. A conquista do espaço físico em detrimento dos povos indígenas representa, no plano cinematográfico, a superioridade da raça branca: a frontier tem suas hierarquias. A descrição estereotipada dos vários tipos raciais e a negação às raças inferiores das promessas e possibilidades da frontier é a consequência lógica dessas hierarquias.

A descrição da fronteira México-EUA é parte dessa lógica. Ela serve para reafirmar a posição inferior de quem vem da terra dos greasers. Escura, perigosa e cheia de ilegalidade, mas, sobretudo, com uma clara diferença entre o lado dos civilizadores e o dos outros, aqueles do outro lado da fronteira, aqueles que ainda não foram civilizados e, talvez, nunca o sejam. Mesmo no espaço indefinido da frontier, há diferenças geográficas que se tornam estereótipos sociais e raciais: não é a mesma coisa viver de um lado ou do outro da fronteira, como se houvesse uma área de frontier boa e outra má. A frontier tem, portanto, uma hierarquia espacial.

Mesmo em períodos históricos de relativa proximidade política entre os Estados Unidos e o México, quando se podia supor uma mudança em termos de imagem na indústria cinematográfica, o estereótipo continuava a ter uma enorme força. Durante a Segunda Guerra Mundial, os dois países se aproximaram, melhorando as relações bilaterais ${ }^{21}$. Em 1942, quando os Estados Unidos, envolvidos na Guerra Mundial, sofriam de grave falta de mão de obra, principalmente agrícola, os governos de Franklin Roosevelt e de Ávila Manuel Camacho criaram o Programa Bracero, que durou até 1962, e permitiu a migração legal de cerca de 5 milhões de mexicanos aos Estados Unidos (SMITH, 2001). 
Nos anos 1950, há aproximadamente 22 filmes hollywoodianos em que aparece a frontier México-EUA. Por exemplo, Touch of Evil, de 1958, uma obraprima do filme noir, e último filme hollywoodiano de Orson Wells, desenvolvese sobre o pano de fundo de uma visão miserável e corrompida de uma cidade imaginária da fronteira mexicana, Los Robles (na realidade, as cenas externas foram filmadas em Venice, Califórnia). O filme tem como protagonistas um funcionário mexicano da Comissão Panamericana antidrogas, Ramon Miguel "Mike" Vargas (Charlton Heston), em lua de mel na Califórnia com a esposa americana, Susan (Janet Leigh); além de um eficaz, mas imoral, policial norteamericano, o capitão Hank Quinlan (Orson Wells).

O filme de Orson Wells representa certa crítica à mentalidade racista vigente no frontier-movie: de fato, Vargas, o mexicano, é um herói positivo a serviço da lei, e não um bandido condenado ao crime devido à sua inferioridade racial (NAREMORE, 1989). Porém, o poder do estereótipo é tanto, que nem mesmo a obra-prima de Wells escapa do uso de imagens e personagens padronizadas, tanto no que se refere à sua descrição, como também à de um dos protagonistas não declarados do filme frontier.

Touch of Evil começa com um dos mais famosos planos-sequência da história do cinema: Vargas e sua esposa Susan estão atravessando a fronteira, e, neste exato momento, alguém coloca uma bomba em um carro (o cronômetro indica que faltam três minutos para a explosão). Eles caminham e cruzam a fronteira para os Estados Unidos, simultaneamente ao carro com a bomba; e, assim que o carro se afasta dos dois recém-casados, a bomba explode. Quem deve investigar o acontecido? O honesto policial mexicano Mike Vargas (Charlton Heston), ou o corrupto detetive americano Hank Quinlan (Orson Welles)? Parece a história típica em que se enfrentam um policial bom e outro mau. Mas, enquanto o mexicano Vargas é descrito como um oprimido, frustrado por um sonho americano que nunca se realizou, o corrupto Quinlan demonstra rapidamente ser uma personagem de grande interesse. No território da frontier, Quinlan representa a evolução do outlaw, e não hesita em usar métodos ilegais para impor sua própria ideia de justiça. Vargas é ainda um herói limitado em suas possibilidades, forçado pelas suas origens a desfrutar da simpatia do público, somente ao representar a bondade e a justiça, como se para ser aceito como herói, ele devesse comportar-se bem. Apenas Quinlan pode desempenhar o papel trágico do herói negativo, amaldiçoado, mas com aspectos humanos - o que o torna definitivamente mais simpático e interessante. Completam o panorama das personagens, o líder de uma gangue de traficantes de drogas de nome italiano, Joe Grandi (Akim Tamiroff), e Tanya, a cigana-quiromante (Marlene Dietrich), dona de um bordel que se encontra, obviamente, no lado mexicano da frontier. A escolha de Welles de gravar o filme em preto e branco (confiando a fotografia ao excelente Russell Metty) enfatiza o aspecto da frontier como um território das sombras - sombras que aumentam, quando se passa pelo lado mexicano. 
Cinematograficamente falando, a fronteira que separa os Estados Unidos do mundo latino estende-se desde a América do Norte à América do Sul, variando amplamente, mudando ao longo do tempo. Ela reflete o sentimento do perigo que vem do Sul (perigo da invasão migratória, do contágio, da importação de drogas, etc.). Assim, a relação que os Estados Unidos têm com os latinos não é mais o resultado de contatos ao longo da área mais ou menos extensa de fronteira, como no greaser-movie, em Bordertown (1935) ou Touch of Evil (1958). Em 1983, com Scarface, Brian De Palma desloca a fronteira pelo território nacional; ela se torna interna, alarga-se, e vai do Caribe até Miami.

Em 2004, com Man on Fire, Tony Scott manda John W. Creasy (Denzel Washington) proteger uma menina na Cidade do México. A fronteira é deslocada para o centro do México, seguindo os medos e sentimentos made in USA, para o local de onde o perigo poderia vir. A menina é filha de uma cidadã norte-americana (Lisa Martin Ramos, apelido Radha Mitchell) e um cidadão mexicano (Samuel Ramos, apelido Marc Anthony). O herói made in EUA é um afro-americano, forte, decisivo, atormentado por pesadelos recorrentes e com experiência no uso de armas: o perfil de um veterano de guerra (a guerra do Iraque começara em 20 de março de 2003). A capital mexicana é caracterizada pela corrupção, crime, perigo, mentiras, e é povoada por pessoas sem escrúpulos. Depois do sequestro da criança, John/Denzel Washington começa a procurá-la à sua maneira, e descobre (depois de convencer com alguma violência alguns moradores locais para dizer a verdade), que no sequestro estão implicados o chefe de polícia, e mesmo o pai da criança, que é um rico empresário mexicano. John Creasy sequestra, tortura e mata os partidários e os membros da gangue, e também os funcionários corruptos da polícia mexicana, e descobre onde a criança se encontra. Acusado por John e também seguido por sua esposa, o senhor Ramos comete suicídio. John recupera a garota para devolvê-la à sua mãe, e vai ao encontro da morte enfrentando os bandidos ${ }^{22}$.

Repleto de violentos estereótipos antilatinos, Man on Fire retrata um México violento e corrupto, nas mãos de policiais e políticos sem qualquer dignidade, e traz um mundo latino em que nenhum valor é respeitado (nem mesmo aqueles familiares). A longa sentença final exclui qualquer possível mistura de raças e culturas diferentes: a loira, mulher branca, é punida com a perda da ilusória paz familiar, por ter pensado em se misturar a um latino e viver fora de seu país; o rico empresário mexicano é punido por se atrever a pensar em se casar com a mulher branca; o mesmo destino é reservado ao afro-americano, que depois de trocar olhares sensuais com a mulher loira e casada, encontra a morte sacrificial e libertadora (expiação por ter se atrevido a pensar na mulher rica e branca; e libertação dos pesadelos gerados por seu ser violento a serviço da justiça) ${ }^{23}$.

Em 2010, Robert Rodriguez e Ethan Maniquis re-colocam a fronteira no território dos Estados Unidos, a poucos quilômetros dos limites com o México, no Texas, onde se desenvolve a história de Machete, interpretado pelo ator norte-americano de origem mexicana, Danny Trejo. Ele é um agente federal 
mexicano, cuja esposa e filha são mortas pelo narcotraficante Rogelio Torrez (Steven Seagal). Fugido para o Texas, Machete é envolvido, contra a sua vontade, no falso ataque ao corrupto e hiper-racista senador do Texas, McLaughlin (Robert De Niro). Ajudado por uma policial de origem mexicana, Rivera Sartana (Jessica Alba) e por uma migrante mexicana, Luz (Michelle Rodriguez), Machete é capaz de derrotar o corrupto senador McLaughlin; como também Von Jackson (Don Johnson), líder de vigilantes paramilitares que matam imigrantes clandestinos, e, finalmente, Rogelio Torrez. O herói Machete é descrito como um bruto, violento e perigoso, que fala apenas palavras monossilábicas (como se tivesse problemas para articular um discurso completo). Ele atrai todas as mulheres com o poder animal do seu ser selvagem e mata sanguinariamente os seus inimigos. O problema da xenofobia é colocado em paródia com um efeito de banalização.

Em 2011, Olivier Megaton empurra elasticamente a fronteira até Bogotá, indo em busca de Cataleya Restrepo (Zoe Saldana), protagonista de Colombiana (filme escrito e co-produzido por Luc Besson). A pequena Cataleya escapa dos assassinos de seus pais, envolvidos no tráfico de drogas, para chegar adulta na Chicago de seu tio, Emilio Restrepo (Cliff Curtis), que Ihe ensinará a ser uma assassina de aluguel. A fronteira elástica de Megaton vai procurar os perigos na Colômbia e os transporta para o coração dos Estados Unidos, para a cidade mais famosa da história do gangster-movie, onde Tony Camonte deu seus primeiros passos em 1932. Bonita e sensual, mas também cruel e mortal, Cataleya é um dos últimos protótipos do criminoso que vem do mundo exterior. Pertencente a nações selvagens e bárbaras e, como tal, com supercapacidades inúteis para aqueles que vivem de forma normal e civilizada, mas muito úteis para aquele que vive em uma selva ou quer viver como criminoso sem escrúpulos.

\section{Cinema e migração: entre velhos estereótipos e novas visões críticas}

O multiplicar-se nas últimas décadas de obras que tratam da realidade migratória, colocando o migrante (ou os filhos dos migrantes de segunda e terceira gerações) no centro da narração, representa um fenômeno notável, que merece ser analisado para compreender como o cinema aborda, testemunha e denuncia um dos temas mais relevantes das sociedades contemporâneas. O nascimento de projetos e networks de pesquisa, como Migrant and Diasporic Cinema in Contemporary Europe (em Londres); Turkish Migrant Cinema in Europe (network de pesquisa internacional); The Kölnischer Kunstverein: Projekt Migration (em Colônia, 2002-2005); Beur is beautiful: A retrospective of Maghrebi-French Cinema (programa internacional itinerante sobre cinema magrebino-francês); ou ainda, o trabalho de Zalab, em Roma (produção de documentários participativos com os próprios migrantes), são expressões de como o cinema sobre migração representa um fenômeno cultural e político de grande importância, e que desperta o interesse do mundo cultural e acadêmico. 
A relação entre cinema e migração muda produzindo uma interessante reflexão sobre nossas sociedades, abrindo novas frentes de pesquisa multidisciplinares. O material audiovisual produzido é vasto e complexo na sua relação com as sociedades sobre as quais reflete; e, nesse sentido, representa um campo de pesquisa novo e interessante.

Nesse contexto, uma reflexão sobre os estereótipos que caracterizam a visão hollywoodiana da migração (e que de forma hegemônica povoam o imaginário fílmico contemporâneo) torna-se necessária e quase propedêutica para delimitar adequadamente a questão da relação entre cinema e fenômeno migratório. Isso porque, trata-se de uma visão estereotipada e preconceituosa, que é produzida (e se reproduz) de forma massiva, e com grande facilidade, desde a era primitiva do cinema, deixando como herança um universo com suas rígidas classificações xenófobas e racistas; classificações capazes de mudar e adaptar-se às regras e às exigências do mercado cinematográfico.

\section{Notas}

1 - There's only one thing that gets orders and gives orders! And this is it. That's how I got the South Side for you and that's how I'm gonna get the North Side for you. Some little typewriter, huh? I'm gonna write my name all over this town with big letters!

2 - Existem pequenas comédias sobre a figura do migrante como, por exemplo: Bianco, rosso e Verdone, dirigido e interpretado por Carlo Verdone (Itália, 1981) que narra, dentre outras coisas, a história de um italiano na Alemanha, descrito segundo os mais estúpidos e vulgares estereótipos sobre a italianidade; L'emigrante (Itália, 1973), de Pasquale Festa Campanile, com a dupla de cantores-atores Adriano Celentano e Claudia Mori. Um discurso à parte pode ser feito por Casa de Mi Padre (USA, 2012), de Armando Alvarez, com Will Ferrell, Gael García Bernal, Diego Luna, em que o louro e alto Will Ferrell interpreta um fazendeiro mexicano falando um espanhol ridículo. Este filme representa uma tentativa de vender o estereótipo do mexicano no mercado dos hispânicos que vivem nos Estados Unidos.

3 - "The ignorant, superstitious Neapolitan or Sicilian, heir of centuries of Bourbon misgovernment, cannot be expected to prove us his race mettle" (ROSS apud BERTELLINI, 2005a, p. 690).

4 - "After allowing for every disturbing factor, it appears that these children, with the dusk of Saracenic or Berber ancestors showing in their cheeks, are twice as apt to drop behind other pupils of their age as are the children of the non-English-speaking immigrants from northern Europe" (ROSS apud BERTELLINI, 2005a, p. 690).

5 - Sobre The Black Hand (1906), In Little Italy (1909), The Detectives of the Italian Bureau (1911), e, sobretudo, sobre filmes dirigidos por D. W. Griffith, isto é, The Musketeers of Pig Alley (1912), The Criminals (1913) e The Padrone's Ward (1913) é possível consultar Bertellini (2004, p. 374-398) e Bertellini (2005b, p. 207-237).

6 - Filho de um casal de imigrantes: a mãe, irlandesa de Cork e o pai, croata da Dalmácia.

7 - Nascida em 1922, a Motion Picture Producers and Distributors of America (que assumirá mais tarde o nome de Motion Picture Association of America) foi fundada para defender os interesses dos principais estúdios de produção cinematográfica. Era integrada por: Walt Disney, Sony Pictures Entertainment, Metro-Goldwyn-Mayer, Paramount Pictures, Twentieth Century Fox, Universal Studios e Warner Bros.

8 - O Production Code elencava três princípios gerais:

a) Não será produzido nenhum filme que reduza o padrão moral dos espectadores. Por este motivo, a simpatia do público não deverá nunca ser direcionada para o crime, comportamentos 
desviantes, o mal ou o pecado.

b) Serão apresentados somente padrões de vida corretos, com as limitações necessárias ao drama e entretenimento.

c) A Lei, natural, divina ou humana, não será nunca exposta ao ridículo, nem nunca será incitada a simpatia do espectador para a sua violação.

9 - Baseado no romance homônimo de Armitage Trail, publicado em 1929.

10 - Após o sucesso de The Godfather, em 1972, Coppola fará mais outros dois. Em 1974, foi lançado The Godfather II, estrelado por Al Pacino, Robert Duvall, Diane Keaton e Robert De Niro. O filme conta, com flashbacks, a história de um jovem, Vito Corleone (Robert De Niro): o massacre de sua família em Corleone, Sicília, pela máfia local (1901); em seguida, a chegada de Vito a Nova York e sua vida como um jovem que se torna chefe da máfia. Ao mesmo tempo, conta a história da família Corleone, em Nevada, liderada por Michael Corleone (Al Pacino), a partir de 1958. Em 1990, The Godfather III, com Al Pacino, Andy Garcia, Diane Keaton. O filme conta a história da família nos anos 1980, com Michael Corleone, que mora em Nova York; é bilionário e goza da reputação de uma pessoa respeitável, mas é velho e doente e deve pensar na sucessão.

11 - É a história de Charlie Cappa (Harvey Keitel) e John Civello, denominado Johnny Boy (Robert De Niro), dois jovens da Little Italy de Nova York, que viviam de modo violento, mesmo porque sofriam com o ambiente violento do bairro onde nasceram.

12 - É a história de Henry Hill, um adolescente ítalo-irlandês, crescido em Brownsville, bairro violento do Brooklyn, Nova York. Junto a seus amigos Jimmy Conway (Robert De Niro) e Tommy DeVito (Joe Pesci), Henry assume a carreira do crime. Eles fazem sucesso nos anos 1960. Com o passar dos anos, Henry entende que os amigos aos quais é ligado são extremamente violentos, e muitas vezes chegam ao assassinato, especialmente Tommy. Henry, afinal, colabora com a justiça e muda de cidade e de vida, protegido pelo $\mathrm{FBI}$, já que é ameaçado pela vingança dos seus ex-companheiros colocados em liberdade. No filme, a personagem da mãe de Tommy De Vito é interpretada por Catherine Scorsese, a mãe do diretor.

13 - Terceiro filme da assim chamada trilogia sobre a máfia de Scorsese é a história do gângster Sam "Ace" Rothstein (Robert De Niro) que se torna um importante gerente de cassinos em Los Angeles por conta da família mafiosa italiana encabeçada por Remo Gaggi. Protagonistas do filme: Robert De Niro, Sharon Stone, Joe Pesci, James Woods. O filme é baseado no romance biográfico de Nicholas Pileggi, Casino: Love and Honor in Las Vegas (1995), baseado por sua vez na história verídica de Frank "Lefty" Rosenthal e Anthony "The Ant" Spilotro.

14 - O termo New Hollywood designa o período de grande renovação do cinema norteamericano, acontecido entre os anos 1960 e os primeiros anos da década de 1980. Nasce uma nova tendência que transforma os diretores em autores (como na Europa) e se abre a temas frequentemente considerados tabus: desconforto juvenil e social, condição da mulher na sociedade, a existência de diferentes sexualidades, reflexão crítica sobre o tratamento às minorias e sobre a guerra.

15 - Fonte de inspiração da série foi o livro de Ness e Oscar Fraley, escrito em 1947, no qual narram eventos acontecidos entre 1929 e 1935 (NESS e FRALEY, 1957).

16 - Em 1993-94 foi gravado um remake composto por duas temporadas.

17 - Home Box Office.

18 - "Say hello to my little friend!"

19 - Do romance de Carroll Graham.

20 - O filme é um dos clássicos do cinema western e em 2007 foi feito dele um remake com o mesmo título. O filme de 2007 foi dirigido por James Mangold, com Russell Crowe no papel de Ben Wade e Christian Bale no papel de Dan Evans.

21 - Esta proximidade foi institucionalizada mediante programas de cooperação (cf. MEYER, 2006).

22 - O filme é um remake de Man On Fire, de Elie Chouraqui (1987), em que Creasy (veterano do Vietnã e Líbano e ex-agente da $\mathrm{ClA}$ ) se encontra na mesma situação na Itália, em Milão. 
23 - Grande nota decepcionante do filme é, obviamente, a presença de Denzel Washington, novo Sidney Poitier e ícone de um cinema empenhado na luta contra o racismo. Conhecido, sobretudo, por ter feito filmes como: Cry Freedom, de Richard Attenborough (1987), sobre a figura do militante pelos direitos raciais na África do Sul, Steve Biko; Glory, de Edward Zwick (1989), sobre o 54ㅇ Regimento de Voluntários de infantaria (composto predominantemente por ex-escravos) durante a Guerra de Secessão americana; Mo' Better Blues, de Spike Lee (1990), melodrama sobre a vida de um afro-americano trompetista de jazz; Mississippi Masala, de Mira Nair (1991), filme que trata a temática antirracista do amor entre um afro-americano e uma indiana nascida na Uganda do ditador Amin; Malcom X, de Spike Lee (1992), baseado na autobiografia de Malcom X; Philadelphia, de Jonathan Demme (1993), sobre os preconceitos contra os doentes de AIDS; The Hurricane, de Norman Jewison (1999), história de um pugilista afro-americano vítima do racismo.

\section{Referências}

BAZIN, André. Ontologie de l'image photographique. In: Qu'est-ce que le cinéma?, tome I, Paris, Éditions du cerf, 1958.

BERTELLINI, Giorgio. Black Hands and White Hearts: Italian Immigrants as "Urban Racial Types" in Early American Film Culture. In: Urban History, no 31, p. 374-398, 2004.

BERTELLINI, Giorgio. Duce/Divo. Masculinity, Racial Identity, and Politics among Italian Americans in 1920s New York City. In: Journal of Urban History. Vol. 31 no. 5, p. 685-726, July, 2005a.

BERTELLINI, Giorgio. Black Hands and White Hearts: Southern Italian Immigrants, Crime, and Race in Early American Cinema. In: GRIEVESON, Lee; SONNET, Esther and STANFIELD, Peter (eds.). Mob Culture: Hidden Histories of the American Gangster Film. Brunswick, NJ: Rutgers University Press, 2005b, p. 207-237.

BORDWELL, David. Classical Hollywood Cinema: National Priciples and Procedures. In: ROSEN, Philip. A Film Theory Reader: Narrative, Apparatus, Ideology. New York: Columbia University Press, 1986, p.17-32.

GARCÍA RIERA, Emilio. México visto por el cine extranjero. t. IV . México: Ediciones Era, 1988. GIRVEN, Tim. Hollywood's Heterotopia: U. S. Cinema, the Mexican Border and the Making of Tijuana. In: Travesía: Journal of Latin American Cultural Studies, vol. 3, no 1-2, p. 93-133, 1994.

KLAHN, Norma. La frontera imaginada, inventada o de la geopolítica de la literatura a la nada. In: SCHUMACHER, Maria Esther (comp.). Mitos en las relaciones México-Estados Unidos. México: Fondo de Cultura Económica, 1994.

NAREMORE, James. The Magic World of Orson Welles. Dallas, Southern Methodist University Press, 1989.

NESS, Eliot e FRALEY, Oscar. The Untouchables. Cutchogue, NY: Julian Messner, 1957.

MEYER, Lorenzo. Estados Unidos y la evolución del nacionalismo defensivo mexicano. In: Foro internacional, no 185, p. 421-464, 2006.

QUART, Leonard e AUSTER, Albert. American Film and Society since 1945. Londres: McMillan Publishers Ltd., 1984.

SMITH, Clint. México y los Estados Unidos. 180 años de relaciones ineludibles. México: Universidad de California en Los Ángeles (UCLA), Universidad de Guadalajara y Juan Pablos, 2001.

VECOLI, Rudolph J. Negli Stati Uniti. In: BEVILACQUA, Piero, De CLEMENTI, Andreina e FRANZINA, Emilio. Storia dell'emigrazione italiana, vol II (Arrivi). Roma: Donzelli, 2002, p. 73-88.

VELAZQUEZ GARCIA, Mario Alberto. La construcción de la imagen de México en Estados Unidos desde una perspectiva de riesgo. In: Frontera Norte. Tijuana, México: El Colegio de la Frontera Norte, v. 20, № 39, p. 37-67, enero/junio, 2008. 


\title{
RESUMO
}

É possível analisar, numa perspectiva diacrônica, a evolução do imaginário fílmico sobre as migrações. Existe um cinema militante (sobretudo nas últimas três/quatro décadas) que é fruto do trabalho e da reflexão de diretores ou grupos de pesquisa (produção de documentários, por exemplo) preocupados com o fenômeno migratório. Mas existe no cinema hollywoodiano clássico, aquele cinema hegemônico que inunda as salas do mundo inteiro, uma forma estereotipada de ver os migrantes. Esta produção de estereótipos condiciona a própria história do cinema e a evolução cinematográfica do século XX e XXI. Quais são as imagens, os estereótipos, as banalizações com as quais foi arquivada a figura do migrante no cinema hollywoodiano? Neste artigo traçamos uma breve introdução sobre a visão de italianos e latinos no cinema dos Estados Unidos, enfatizando o nascimento dos estereótipos sobre os migrantes.

Palavras-chave: italianos; latinos; Hollywood.

\begin{abstract}
It's possible to analyze the evolution of the cinematographic imagery of migration from a diachronic perspective. One can identify both a militant stream of filmmaking (especially in the last 3-4 decades), due to the efforts and reflections of single directors and research groups, worried about the social issues related to migration and trying to give resonance to this important phenomenon, and an Hollywood-based, widely distributed category of movies, promoting a stereotyped view of migrants. This massive production of stereotypes influences the very history and evolution of the cinematography in the 20th and 21st century. What images, stereotypes, trivializations caused the figure of the migrant to be hastily dismissed? In this article, we try to sketch an introduction to the perception of italian and latin immigrants in american cinema, underlying the introduction of racial stereotypes.
\end{abstract}

Keywords: italians; latinos; Hollywood. 